\title{
Ductal Carcinoma In Situ. Interventional Diagnosis
}

\author{
Carmen Lisencu1", Mihai Lesaru ${ }^{2,3}$ \\ 'Breast Tumor Center, "Prof. Dr. Ion Chiricuță" Institute of Oncology, Cluj-Napoca, Romania \\ 2Department of Radiology and Medical Imaging, „Carol Davila” University of Medicine and Pharmacy, Bucharest, Romania \\ ${ }^{3}$ Department of Radiology and Medical Imaging, Clinical Institute „Fundeni”, Bucuresti, Romania
}

*Corresponding author: Carmen Lisencu, MD Breast Tumor Center "Prof. Dr. Ion Chiricutăa" Institute of Oncology, Cluj-Napoca, Romania E-Mail: carmen_lisencu@yahoo.com
Received: 19.10.2021 Accepted: 25.11.2021

\section{Rezumat}

Cele mai multe carcinoame in situ sunt oculte clinic, astfel încât pentru un diagnostic optim este importantă utilizarea tehnicilor adecvate. Ghidurile curente recomandă biopsierea preoperatorie a tuturor formațiunilor mamare suspecte de malignitate, prin proceduri minim invazive. Indiferent de tehnicile utilizate, biopsiile efectuate corect, reprezentative geografic, dimensional şi numeric sunt esențiale şi permit plasarea de marcaje în locul de interes după efectuarea procedurii intervenționale. Ori de câte ori este posibil, se indică utilizarea biopsiei asistate cu vacuum prin ghidaj mamografic ca primă opțiune de biopsiere a leziunilor mamare nepalpabile, în special pentru microcalcificări. Majoritatea carcinoamelor ductale in situ vor fi excizate chirurgical; ca urmare, sunt necesare tehnici speciale pentru reperajul preoperator al leziunilor în vederea unei excizii corecte, cu margini libere de boală şi acceptabile din punct de vedere cosmetic. $\mathrm{Nu}$ s-au constatat diferențe semnificative de performanță între localizarea cu harpon, localizarea radioghidată sau cea prin tehnica semințelor radioactive, iar alegerea modalitătiii de ghidare imagistică ar trebui să ia în considerare cea mai bună vizibilitate a leziunii sau a markerului. În lucrarea de față am efectuat o recenzie a principalelor proceduri intervenționale utilizate în diagnosticul carcinomului ductal in situ, ilustrate cu imagini din baza de date a Institutului Oncologic ClujNapoca şi a Institutului Clinic Fundeni.

Cuvinte cheie: carcinom ductal in situ, biopsie, localizare preoperatorie, ghidaj imagistic 


\begin{abstract}
Most ductal carcinomas in situ are clinically occult; therefore, proper techniques must be used for adequate diagnosis. Current guidelines recommend minimally invasive tissue sampling before surgical excisions of all breast malignancies. Regardless of the technique used, correctly performed biopsies that are geographically, dimensional and numerical representative are essential, and post-interventional markers can be placed at the site. Whenever possible, vacuum-assisted guided by mammography should be the first choice of biopsy for all nonpalpable lesions of the breast, especially for microcalcifications. Surgical excision is expected in most ductal carcinomas in situ; therefore, appropriate imaging-guided localization techniques must be deployed in the hope of aiding the surgeon to perform a free-margin cosmetically adequate procedure. No significant performance differences have been noticed by comparing wire localization to radio guided occult lesion localization or radioactive seed technique, while the choice of imaging guidance should consider the best visibility of the lesion or marker. In the current paper we review the main interventional procedures used for diagnosis in ductal carcinoma in situ, illustrated with images from the database of the Cluj-Napoca Institute of Oncology and Fundeni Clinical Institute.
\end{abstract}

Key words: ductal carcinoma in situ, biopsy, preoperative localization, imaging guidance

\section{Introduction}

Up to $90 \%$ of ductal carcinomas in situ (DCIS) are detected through mammography $(1,2)$. The majority of DCIS present themselves as microcalcifications $(3,4)$, with an insignificant percentage associated with breast asymmetries, architectural distortion or focal nodular patterns. Merely 5\% of all DCIS are linked to a palpable mass in the breast (5). Surgical excision is the gold standard treatment of DCIS nowadays (6). Therefore, appropriate techniques must be used to ensure optimal diagnosis through biopsy and proper treatment for mostly clinically occult diseases.

\section{Minimally Invasive Tissue Sampling}

For a long time, surgical breast biopsy was the gold standard for lesions without a palpable mass (7). Nowadays, guidelines worldwide indicate that most patients should undergo a minimally invasive biopsy to diagnose the lesions before surgery (8). Mammography aids in detecting up to $90 \%$ of DCIS by identifying abnormalities, most of them being microcalcifications (3). However, those are a non- specific indicator for breast diseases as they can also be found in benign conditions (9). Thus, classification and stratification of highrisk microcalcifications are mandatory and help in the decision-making process for performing a biopsy. A delicate balance must be attained between performing biopsies for too many benign breast diseases and underdiagnosing DCIS (6). Lack of a palpable mass or tumor in the breast requires adequate biopsy and tissue sampling techniques and minimally invasive procedures should always be imaging-guided.

When most screening programs for breast cancer around Europe started, cytology for diagnosis was usually obtained through FineNeedle Aspiration (FNA). However, nowadays, FNA is considered inadequate for proper assessment of DCIS as it cannot distinguish between in situ lesions and invasive malignancies. A study demonstrated a sensitivity for detecting malignancies through FNA of a little over 50\% (10). Also, FNA is highly dependent of the operator and the pathologist that is performing the evaluation; therefore, a high false negative rate can be expected from less experimented centers. Therefore, two 
biopsy techniques for minimally invasive tissue sampling stand today: core-needle biopsy (CNB) and vacuum-assisted biopsy (VAB), both being performed under imaging guidance.

\section{Core-needle Biopsy}

Published in 1994, a study conducted on more than 6000 patients concluded that breast biopsy using a 14-G (Gauge) needle is a viable option and more convenient than a surgical biopsy (11). Ever since then, this method quickly became the benchmark for breast tissue sampling. This is a swift procedure, with an easy learning curve with many automated or semi-automated needles widely available on the market (7). Another advantage is the relatively inexpensive cost for such procedures. While for palpable tumors, the role of simple core-needle biopsy is undisputed (12), for microcalcifications, the core-needle tissue sampling can only be done under adequate imaging guidance (13). Ultrasonography (US) guidance is feasible if proper identification of the cluster can be obtained with an accurate description of the depth, nipple distance, and quadrant situation (13).
In addition, some calcifications are accompanied by other breast tissue changes, making US-guided biopsy more accurate (14). For this particular scenario, US-guided tissue sampling will yield more malignant results at a later pathology examination as the changes identified on the US are the very ones that correlate better with neoplasia than plain calcifications (15). Also, most microcalcifications visible at US examinations are associated with malignancies, as benign calcifications are hardly detected by US (15). Control mammography can be applied to retrieved specimens after biopsy. It is estimated that a minimum of 3 cores with calcium or five flecks of calcium are necessary to ensure proper pathology diagnosis (16). In Fig. 1, on mammography can be seen amorphous microcalcifications with segmental disposal, traced on ultrasound in dilated ducts and radiologically identified on 4 of 5 biopsy specimens (Fig. $1 A, B, C$ ).

One disadvantage of the CNB is that it requires multiple insertions, thus making it more uncomfortable for the patient (17). A downside for US guidance is that it cannot correctly estimate microcalcifications (18). False-negative results with understaging and underestimation, even up to a $40 \%$ rate, are

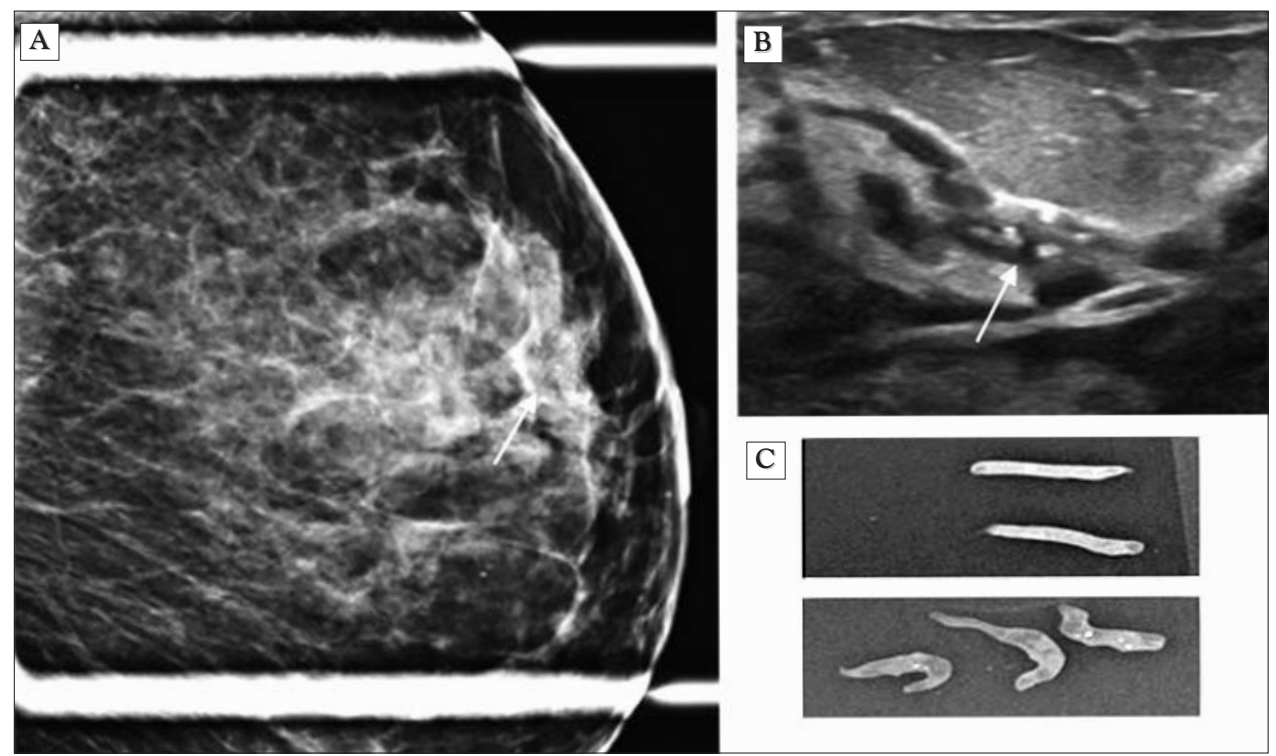

Figure 1. (A) Mammography aspect: amorphous microcalcifications with segmental disposal (arrow); (B) US aspect: dilated ducts with microcalcifications (arrow); (C) Mammography aspect of 5 specimens, of core-needle biopsies, out of which 4 have microcalcifications 
expected when microcalcifications are the only lesions in the breast $(15,18,19)$. This rate can be influenced by the experience of the specialist, by guidance, by the nature of the breast, and the device used (20). Therefore, other imaging techniques can be used for CNBs, such as mammography with stereotactic localization. Computer analysis is being performed from more incidences of mammography to locate the lesion site accurately (16). After that, the needle is inserted, and a biopsy is performed. This procedure can be done with the patient either standing down or lying on a specially designed bed. Mammography guidance also presents a disadvantage for mammographically occult lesions (13). Special procedures such as MRI guidance can be applied (13). However, they are less common and cost-effective, although the MRI has the best detection rate for microcalcifications (21). Regardless of the imaging localization technique used, the core-biopsy tissue has a significant disadvantage: the small size of the samples. To overcome this, subsequent procedures have been developed, such as vacuum-assisted biopsies (22-24).

\section{Vacuum-assisted Tissue Sampling}

While usually the core-needle biopsy uses a 14-G needle, the vacuum-assisted procedure can take advantage of bigger needles, usually between 7 and $12-\mathrm{G}(7)$, that provide tissue in quantity similar to surgical biopsies. Larger sample volumes can ensure a more comprehensive evaluation of the lesions and lower false-negative results $(22,23)$. Pathology examination may take longer since there is more tissue to scan, but overall, this method offers an accurate diagnosis for microcalcifications. Moreover, a single insertion can provide adequate material, thus making this procedure more bearable for the patients (17). In Fig. 2 are exemplified the macroscopic and radiological aspect of specimens harvested through core-needle biopsy and vacuum-assisted biopsy (Fig. $2 \mathrm{~A}, \mathrm{~B}$ ). Nowadays, vacuumassisted tissue sampling should be the first choice for lesions without palpable masses,
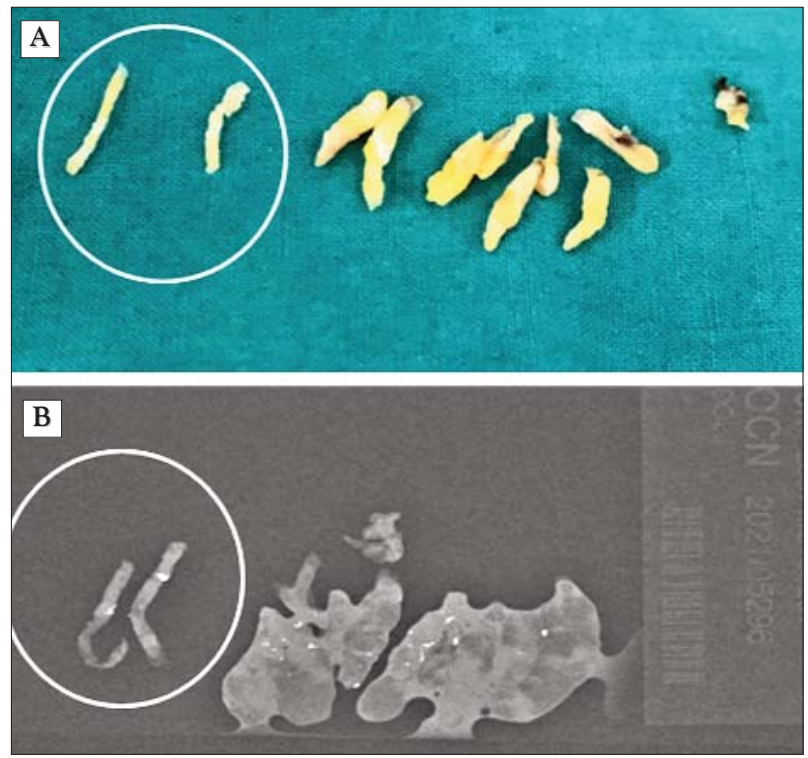

Figure 2. (A) Macroscopic aspect and (B) Mammography aspect of core-needle biopsies using a 14-G needle with 2 insertions (circle) vs. vacuum assisted biopsies using a 9-G needle, one insertion

especially regarding microcalcifications $(7,13)$. Similar to a CNB, the vacuum-assisted one can be US-guided, MRI-guided or mammography guided. Again, US-guidance requires caution as some calcifications cannot be assessed adequately by this examination, although the visible ones have a higher chance of being associated with malignancy. Harvesting under US guidance is also difficult because small amounts of air can be introduced during the procedure, that directly affect the quality of the image. In Fig. 3, microcalcifications can be seen on mammography and on ultrasound examination, while during the vacuum-assisted biopsy under USguidance, beside the needle insertion it can be seen the air artifact (Fig. 3). As for the CNB, a stereotactic approach can be used for mammography-guided vacuum-assisted biopsies (VABs).

Currently, vacuum-assisted tissue sampling, mammography guided with a stereotactic approach, is considered the most accurate method in the diagnosis of suspicious microcalcifications, with the lowest risk of false negative results and underestimation, by collecting larger and more evocative fragments. 


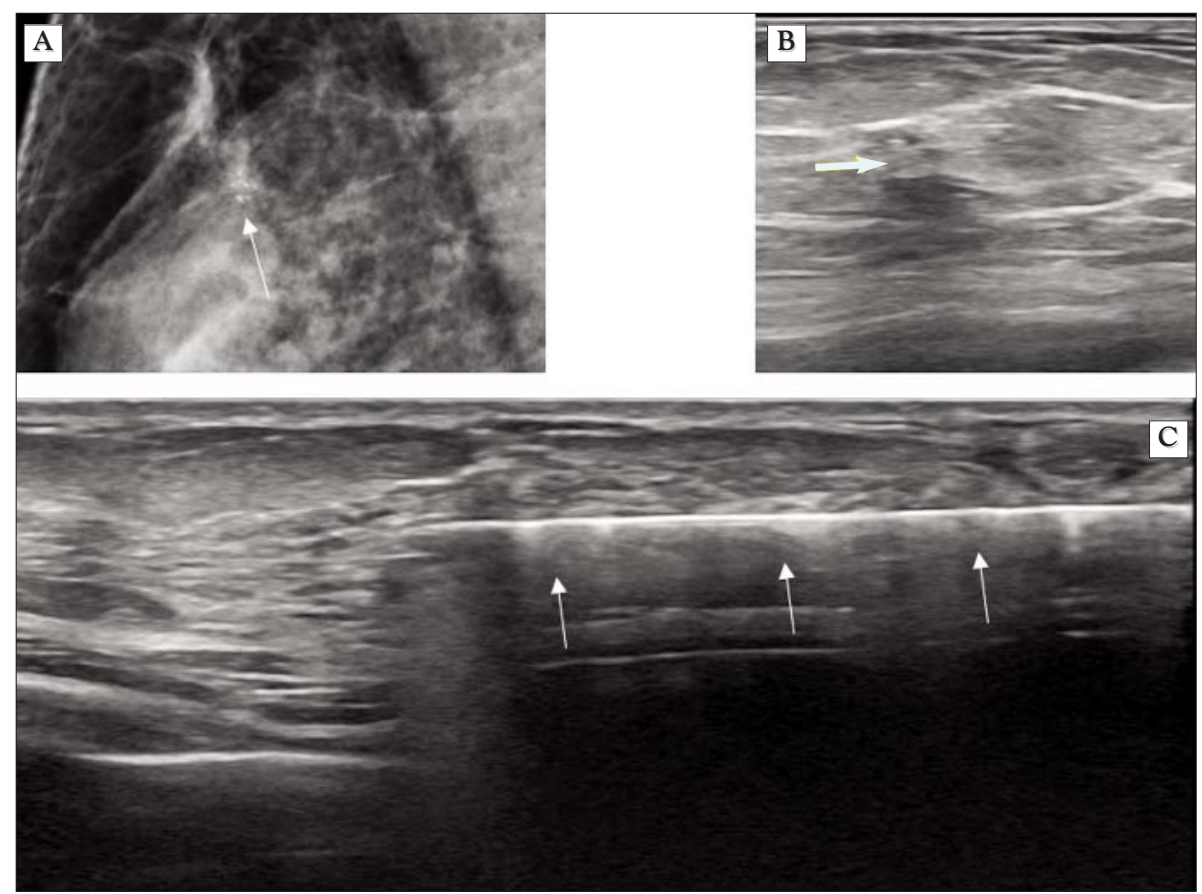

Figure 3. (A) Mammography: microcalcifications in a round distribution (arrow); (B) US aspect of calcifications (arrow); (C) US guided vacuum assisted biopsy, needle insertion and air artifact (arrows)

Like CNB, bleeding, bruising and pain can complicate this procedure $(12,13,18)$. In addition, patients undergoing a VAB have a higher chance of bleeding and developing hematoma or pneumothorax than those who undergo core-needle procedures (25), while hemostasis can be harder to achieve (26). Some other disadvantages for the vacuumassisted tissue samplings include a higher cost per procedure (27) and a longer duration for the biopsy. Even so, vacuum-assisted with mammography guidance and a stereotactic approach should be the first choice of biopsy for all nonpalpable lesions of the breast. Figure 4 illustrates the positioning of the patient, the mammographic aspect of the affected area, the needle positioning with the opening above the affected area and the control of the biopsy sites (Fig. $4 A, B, C, D$ ). However, this technique becomes challenging to perform for small breasts, mammographically occult lesions, skin or chest wall involvement, and retroareolar localization. For these instances, a surgical biopsy is recommended for proper assessment of the microcalcifications (20).

Regardless of the procedure used for tissue sampling, marker deployment must be taken into account after biopsy, as it offers the possibility of quick identification of the site later on, in order to achieve a proper surgical treatment in case of malignancy (28). Fig. 5 illustrates the complete excision of the microcalcifications under VAB (Fig. 5). Fig. 6 illustrates the mammography aspect of a specimen after a surgical excision with a titan marker placed inside the affected area after a stereotactic wire localization (Fig. 6).

\section{Surgical Biopsy and Preoperative \\ Imaging-guided Localization}

Clinically occult DCIS amenable to surgical excision must be appropriately localized and marked accordingly in order for the surgery to be performed optimally with good margins and acceptable cosmetic sacrifices (29-31). There are multiple localization techniques 


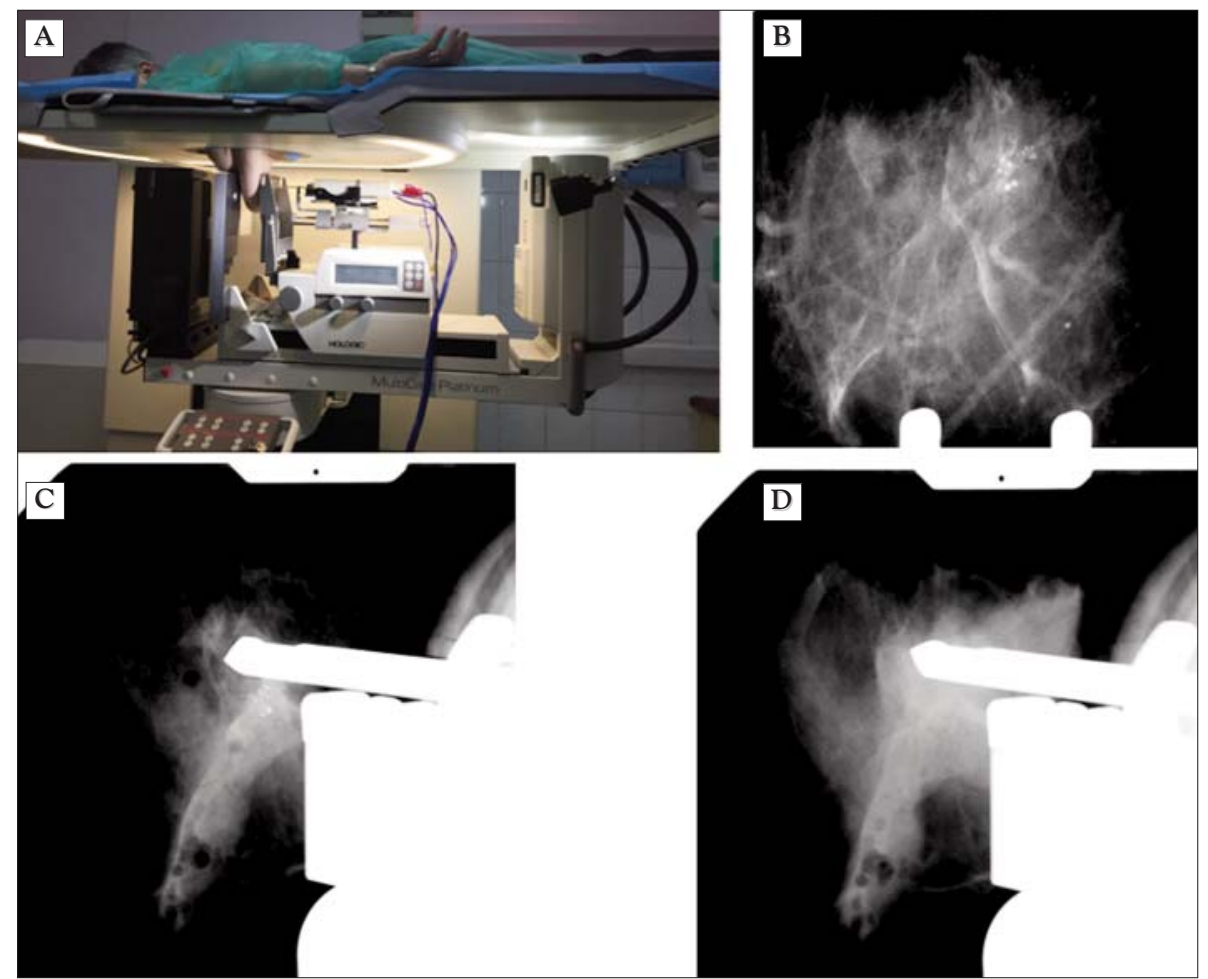

Figure 4. (A) VAB stereotactic guided under mammography, prone position; (B) Mammography showing affected area; (C) Needle positioning with the opening above the affected area; (D) Checking the biopsy site, during the biopsy (complete excision)

similar to those used for tissue sampling. While the choice can vary according to the technologies available, experience, and personal preferences, the general recommendation is to use the technique that offers the best visibility for the lesion, or the marker placed after the biopsy (13). For example, microcalcifications are usually visible only on mammogram; therefore, this examination should be the first choice for good localization. Here, the role of post tissue-sampling marker placement is evident as it can facilitate

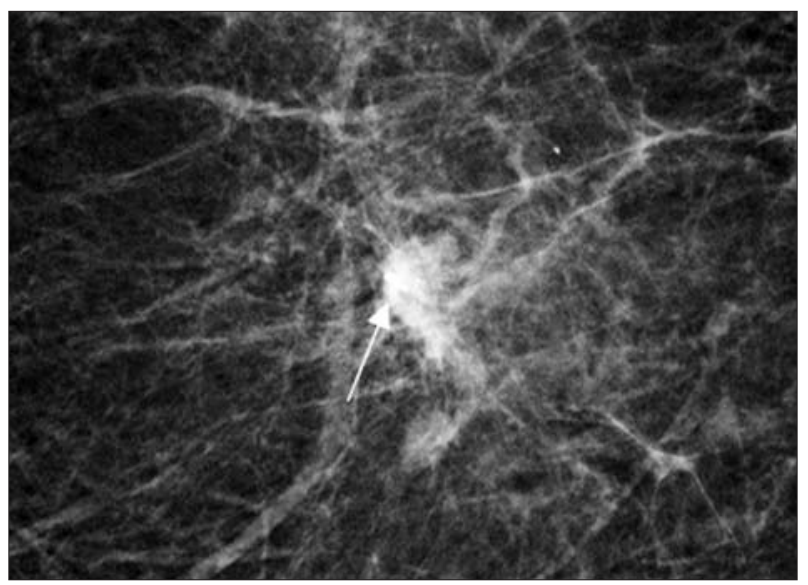

Figure 5. $\quad V A B$ with complete excision of the microcalcification area. Marker deployed (arrow)

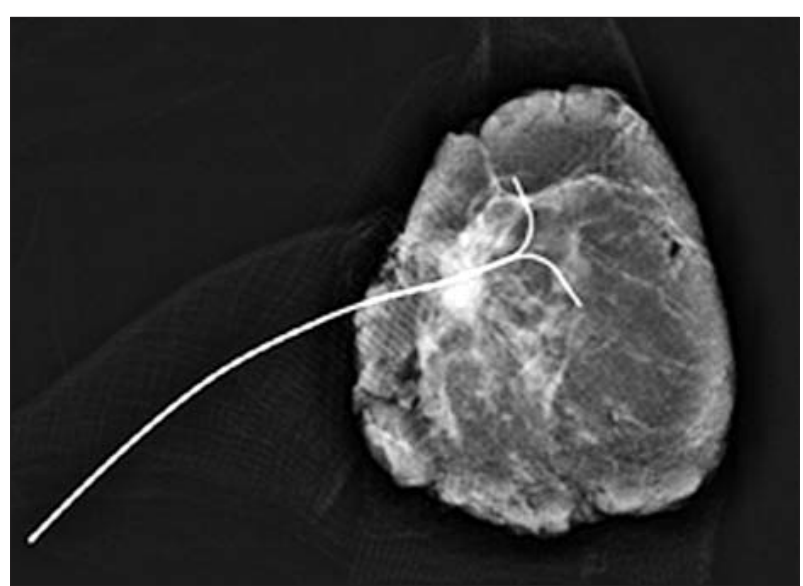

Figure 6. VAB with a DCIS diagnosis. Surgical excision specimen with a titan marker inside the affected area after stereotactic wire localization 
US-guided localization in the case of USvisible markers, easing the preoperative detection of the lesion with a simple, inexpensive, and widely available examination (28).

After proper identification of the marker or lesion, several techniques can be applied for the preoperative localization.

Wire localization is the most common used procedure. A 16 to $21-\mathrm{G}$ co-axial needle is introduced through the skin while a variablelength wire is inserted through the needle via mammography or MRI guidance into the lesion or nearby, where it is anchored with a hook. Fig. 7 illustrates the preoperative wire localization of microcalcifications on mammography in MLO and CC projection (Fig. 7 A, B). The surgical specimen and its margins are always evaluated by a mammography performed during surgery. Fig. 8 illustrates the marker deployed and wire localization on mammography in MLO and CC projection of the affected area, and the mammography of the surgical excision specimen (Fig. $8 \mathrm{~A}, \mathrm{~B}, \mathrm{C}$ ). The excess wire is taped to the skin until the transfer of the patient to the operating room. This is a safe and cost-effective method that can guide the surgeon properly. Some complications that can arise are wire rupture, migration, or infections, but they can be mitigated with proper time management between wire insertion and surgical excision (32).

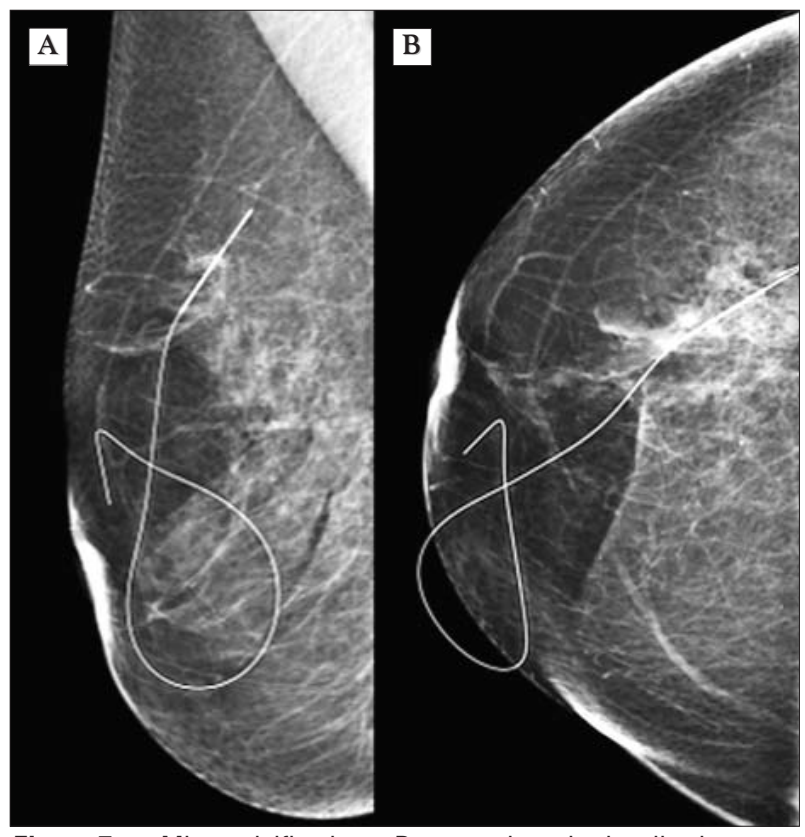

Figure 7. Microcalcifications: Preoperative wire localization on mammography in MLO projection (A) and CC projection (B)

Carbon marking consists of injecting charcoal powder at the site under US or mammography guidance and leaving a trail to the skin. This procedure has the advantage of persistence in the breast, allowing the surgery to be performed even after a month from the injecting time (33). However, the downside is that the tracer can efficiently distribute in the breast tissue leading to imprecise localization (33).

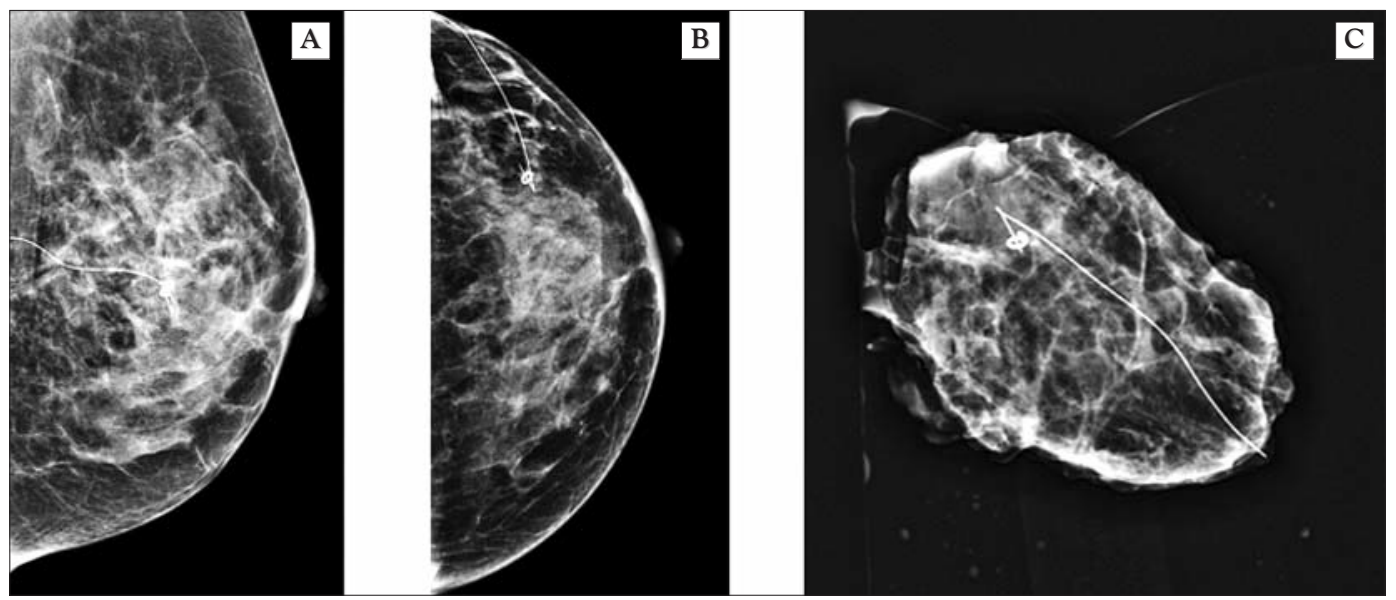

Figure 8. $\quad$ VAB with complete excision of the affected area. Marker deployed and wire localization on mammography in MLO projection (A) and CC projection (B); (C) Mammography of the surgical excision specimen 
Radio Guided Occult Lesion Localization (ROLL) requires injecting radioactive technetium inside the lesion that will be intraoperatively localized with a gamma probe (34). The injection of radioactive substance presents the advantage of identifying the occult lesion localization and in the same time the sentinel lymph node localization (SNOLL procedure) (35). However, these techniques are very experience-dependent and more expensive.

Seed localization can use radioactive (36) or magnetic (37) seeds inserted at the site that can be later localized with gamma and magnetic probes, respectively. They have similar success rates to the ROLL procedure; however, the titanium seeds can be left inside the lesion for more extended periods, allowing for delayed surgery.

A meta-analysis evaluated eight Randomized Controlled Trials (RCTs) compared the efficacy of wired localization, ROLL, and radioactive seed and found no significant difference between them (38). Therefore, appropriate preoperative localization has to consider the cost-efficiency rate, the experience of the center and personal preferences of both the radiologist and the surgeon.

\section{Conclusions}

Most DCIS are clinically occult; therefore, proper techniques must be used for adequate diagnosis. Current guidelines recommend minimally invasive tissue sampling before surgical excisions of all breast malignancies. Regardless of the technique used, correctly performed biopsies that are geographically, dimensional, and numerical representative are essential, while post-interventional markers can be placed at the site. Whenever possible, vacuum-assisted guided by mammography should be the first choice of biopsy for all nonpalpable lesions of the breast, especially for microcalcifications. Surgical excision is expected in most DCIS; therefore, appropriate imaging-guided localization techniques must be deployed in the hope of aiding the surgeon to perform a free-margin cosmetically adequate procedure. No significant performance differences have been noticed by comparing wire localization to ROLL or radioactive seed, while the choice of imaging guidance should consider the best visibility of the lesion or marker.

\section{Conflict of Interests}

The authors declare no conflicts of interests.

\section{References}

1. Weaver D, Rosenberg R, Barlow W, Ichikawa L, Carney P, Kerlikowske K et al. Pathologic findings from the Breast Cancer Surveillance Consortium. Cancer. 2006;106(4):732-742.

2. Mannu G, Wang Z, Broggio J, Charman J, Cheung S, Kearins 0 et al. Invasive breast cancer and breast cancer mortality after ductal carcinoma in situ in women attending for breast screening in England, 1988-2014: population-based observational cohort study. BMJ. 2020 May 27;369: m1570.

3. Shehata M, Grimm L, Ballantyne N, Lourenco A, Demello L, Kilgore M et al. Ductal Carcinoma in Situ: Current Concepts in Biology, Imaging, and Treatment. J Breast Imaging. 2019;1(3):166-176.

4. Barreau B, Mascarel I, Feuga C, MacGrogan G, Dilhuydy M, Picot V et al. Mammography of ductal carcinoma in situ of the breast: review of 909 cases with radiographic-pathologic correlations. Eur J Radiol. 2005;54(1):55-61.

5. Salvatorelli L, Puzzo L, Vecchio G, Caltabiano R, Virzì V, Magro G. Ductal Carcinoma In Situ of the Breast: An Update with Emphasis on Radiological and Morphological Features as Predictive Prognostic Factors. Cancers. 2020;12(3):609.

6. Virnig B, Tuttle T, Shamliyan T, Kane R. Ductal Carcinoma In Situ of the Breast: A Systematic Review of Incidence, Treatment, and Outcomes. JNCI Journal of the National Cancer Institute. 2010;102(3):170-178.

7. Wilkinson L, Thomas V, Sharma N. Microcalcification on mammography: approaches to interpretation and biopsy. Br J Radiol. 2017;90(1069): 20160594. Epub 2016 0ct 17.

8. Breast Cancer [Internet]. NCCN Clinical Practice Guidelines in Oncology. 2021 [cited 22 June 2021]. Available from: https://www.nccn.org/ professionals/physician_gls/pdf/breast.pdf

9. O'Grady S, Morgan M. Microcalcifications in breast cancer: From pathophysiology to diagnosis and prognosis. Biochimica et Biophysica Acta (BBA) - Reviews on Cancer. 2018;1869(2):310-320.

10. NHS breast screening: non operative diagnostic procedures [Internet]. NHS breast screening: non operative diagnostic procedures. 2021 [cited 22 June 2021]. Available from: https://www.gov.uk/government/publications/ nhs-breast-screening-non-operative-diagnostic-procedures

11. Parker S, Burbank F, Jackman R, Aucreman C, Cardenosa G, Cink T et al. Percutaneous large-core breast biopsy: a multi-institutional study. Radiology. 1994;193(2):359-364.

12. Core Needle Biopsy of the Breast I Core Needle Biopsy [Internet]. Core Needle Biopsy of the Breast. 2021 [cited 27 June 2021]. Available from: https://www.cancer.org/cancer/breast-cancer/screening-tests-and-earlydetection/breast-biopsy/core-needle-biopsy-of-the-breast.html

13. Bick U, Trimboli R, Athanasiou A, Balleyguier C, Baltzer P, Bernathova M et al. Image-guided breast biopsy and localisation: recommendations for information to women and referring physicians by the European Society of Breast Imaging. Insights Imaging. 2020;11(1):12

14. Kim T, Kim D, Jung J, Lee E. Sonographic Visibility and Feasibility of Biopsy under Ultrasound Guidance of Suspicious Microcalcification-only Breast Lesions: a Single-centre Study. Hong Kong Journal of Radiology. 2015;18:125-133.

15. Bae S, Yoon J, Moon H, Kim M, Kim E. Breast Microcalcifications: Diagnostic Outcomes According to Image-Guided Biopsy Method. Korean J Radiol.2015;16(5):996-1005 
16. Bagnall M, Evans A, Wilson A, Burrell H, Pinder S, Ellis I. When have Mammographic Calcifications been Adequately Sampled at Needle Core Biopsy?. Clinical Radiology. 2000;55(7):548-553.

17. Soo A, Shelby R, Miller L, Balmadrid M, Johnson K, Wren A, et al. Predictors of pain experienced by women during percutaneous imagingguided breast biopsies. J Am Coll Radiol. 2014;11(7):709-16.

18. Fusco R, Petrillo A, Catalano O, Sansone M, Granata V, Filice $S$ et al. Procedures for location of nonpalpable breast lesions: a systematic review for the radiologist. Breast Cancer. 2012;21(5):522-531.

19. Houssami N, Ciatto S, Ellis I, Ambrogetti D. Underestimation of malignancy of breast core-needle biopsy. Cancer. 2007;109(3):487-495.

20. Badruddoja M. Ductal carcinoma in situ of the breast: a surgical perspective. Int J Surg Oncol. 2012;2012:761364.

21. Baltzer P, Bennani-Baiti B, Stöttinger A, Bumberger A, Kapetas P, Clauser P. Is breast MRI a helpful additional diagnostic test in suspicious mammographic microcalcifications?. Magn Reson Imaging. 2018;46:70-74. Epub 2017 Nov 6.

22. Park H, Kim L. The current role of vacuum assisted breast biopsy system in breast disease. J Breast Cancer. 2011;14(1):1-7.

23. Saikia S, Lunt L. Vacuum-assisted core biopsy of the breast. Breast Cancer Research. 2011;13(S1).

24. Schrader S, Distelmaier M, Dirrichs T, Detering S, Brolund L, Strobel K et al. Digital Breast Tomosynthesis-guided Vacuum-assisted Breast Biopsy: Initial Experiences and Comparison with Prone Stereotactic Vacuumassisted Biopsy. Radiology. 2015;274(3):654-662.

25. Simon J, Kalbhen C, Cooper R, Flisak M. Accuracy and Complication Rates of US-guided Vacuum-assisted Core Breast Biopsy: Initial Results. Radiology. 2000;215(3):694-697.

26. Ferzli G, Hurwitz J. Initial experience with breast biopsy utilizing the advanced breast biopsy instrumentation (ABBI). Surgical Endoscopy. 1997; 11(4):393-396

27. Fernández-García P, Marco-Doménech S, Lizán-Tudela L, Ibáñez-Gual M, Navarro-Ballester A, Casanovas-Feliu E. Estudio de costo-efectividad de la biopsia mamaria asistida por vacío versus biopsia con aguja gruesa 0 arpón. Radiología. 2017:59(1):40-46.

28. Thomassin-Naggara I, Lalonde L, David J, Darai E, Uzan S, Trop I. A plea for the biopsy marker: how, why and why not clipping after breast biopsy? Breast Cancer Res Treat. 2012;132(3):881-93. Epub 2011 Nov 1.

29. Hayes M. Update on Preoperative Breast Localization. Radiol Clin North Am. 2017:55(3):591-603.

30. Cheang $\mathrm{E}, \mathrm{Ha} \mathrm{R}$, Thornton C, Mango $\mathrm{V}$. Innovations in image-guided preoperative breast lesion localization. Br J Radiol. 2018;91(1085): 20170740.

31. Jeffries D, Dossett L, Jorns J. Localization for Breast Surgery: The Next Generation. Arch Pathol Lab Med. 2017;141(10):1324-1329.

32. Helvie M, Ikeda D, Adler D. Localization and needle aspiration of breast lesions: complications in 370 cases. AJR Am J Roentgenol. 1991;157(4): 711-4.

33. Rose A, Collins J, Neerhut P, Bishop C, Mann G. Carbon localisation of impalpable breast lesions. Breast. 2003;12(4):264-9.

34. Leidenius M. Radioguided occult lesion localization (ROLL) in surgery of impalpable breast tumours. Breast Cancer Online. 2005;8(6).

35. Monti S, Galimberti V, Trifiro G, De Cicco C, Peradze N, Benelli F et al. Occult Breast Lesion Localization plus Sentinel Node Biopsy (SNOLL): Experience with 959 Patients at the European Institute of Oncology. Annals of Surgical Oncology. 2007;14(10):2928-2931.

36. Gray R, Salud C, Nguyen K, Dauway E, Friedland J, Berman C et al. Randomized Prospective Evaluation of a Novel Technique for Biopsy or Lumpectomy of Nonpalpable Breast Lesions: Radioactive Seed Versus Wire Localization. Annals of Surgical Oncology. 2001;8(9):711-715.

37. Price E, Khoury A, Esserman L, Joe B, Alvarado M. Initial Clinical Experience With an Inducible Magnetic Seed System for Preoperative Breast Lesion Localization. American Journal of Roentgenology. 2018;210(4):913-917.

38. Chan B, Wiseberg-Firtell J, Jois R, Jensen K, Audisio R. Localization techniques for guided surgical excision of nonpalpable breast lesions. Cochrane Database Syst Rev. 2015;(12):CD009206. 